\title{
Implementasi Good Governance Di Indonesia
}

\author{
${ }^{1}$ Fitria Andalus Handayani, ${ }^{2}$ Mohamad Ichsana Nur
}

\footnotetext{
${ }^{1}$ Ilmu Administrasi Fakultas Ilmu Administrasi Universitas Indonesia; andalus.hamazah@gmail.com

${ }^{2}$ Administrasi Publik Fakultas Ilmu Sosial \& Ilmu Politik UIN Sunan Gunung Djati Bandung; mohamadichsana22@uinsgd.ac.id
}

\begin{abstract}
The good governance promoted by the World Bank and UNDP still has no a definitive agreement. This concept is more interpreted as a solution for the realization of effective and efficient government performance. Furthermore, the World Bank as a donor provides assistance to countries to build institutional capacity and training for public officials to improve their competence. The methodology in this study employes descriptive qualitative data collection techniques with literature review. The good governance as a concept reaps criticism in its implementation, one of the criticisms given is the lack of control in the implementation of good governance in governmental actors. Not only that the application of good governance in a country is often forced, even though the principle does not fit into the existing government system, state, culture of society. In Indonesia case in terms of Good Governance implementation, there are still many problems such as bureaucratic reform that is not good, practices of KKN, demands for the application of good governance principles which among them are not in accordance with the local characteristics of the Indonesian people, and the participation is still low.
\end{abstract}

Keywords: Governance, good governance, Implementation, World Bank, UNDP.

\section{Pendahuluan}

Harvorsen menyebutkan perbedaan antara World Bank dan UNDP. Didalam buku ini membahas mengenai istilah good governance dan global economic menurut pandangan World Bank dan UNDP. Masih belum ada titik temu mengenai esensi dan pengertian terkait Good Governance. Dalam kaitan ini perdebatan tentang good governance, dilihat dari perspektif bagaimana aktor multilateral (Bank Dunia dan UNDP) menggunakan kategori Good Governance dalam strategi pembangunan mereka. Dengan menggunakan dua pendekatan yang berbeda untuk Good Gevernance, salah satunya adalah terkait dengan rezim neoliberal global dan wacana liberalisasi ekonomi, Bank Dunia menempatkan tata kelola ekonomi (economic governance) yang bertujuan untuk perbaikan tata kelola ekonomi yang mendukung administrasi negara, dimana anti korupsi adalah faktor kunci penting yang membagi secara jelas antara politik dan ekonomi.

Menurut Bank Dunia, economic governance dapat berjalan dengan baik apabila ekonomi pasar dapat berjalan, dan hal tersebut perlu dirancang seorang pengambil keputusan yang rasional. Bank Dunia memandang bahwa keahlian ekonomi adalah penting, sementara itu hak asasi manusia yang penting, meliputi hak untuk memiliki property dan perlindungan hak milik seseorang disamping perlindungan dari pasar dan state violence. Disisi lain, UNDP melihat Good Governance sebagai tata pemerintahan yang demokratis (democratic governance), yang menekankan pada proses demokratisasi dari bawah, fokusnya adalah dalam konteks politik dari negara dan pemahaman struktur kekuasaan dan bagaimana 
perubahan struktur kekuasaan secara demokratis. Demokrasi bukan hanya cara untuk memecahkan masalah-masalah politik praktis tetapi juga cara untuk transformasi identitas seperti dunia simbolis dari inklusif dan solidaritas kebangsaan. Proses pengambilan keputusan, serta gerakan populer yang tumbuh dari masyarakat sipil.

World Bank, sebagai salah satu lembaga donor keuangan dunia menganggap bahwa globalisasi merupakan salah satu solusi untuk meningkatkan ekonomi setiap negara-negara yang ada di dunia. Namun globalisasi dapat dianggap sebagai suatu tantangan dan juga suatu masalah bagi negara-negara yang menggunakan sistem demokrasi di dalam hubungan antara negara dan masyarakatnya. World Bank pun memperkenalkan prinsip good governance di dalam hubungan antara negara dengan masyarakatnya. Prinsip-prisip kerja administrasi publik dalam good governance dianggap sebagai salah satu cara untuk meningkatkan ekonomi setiap negara, salah satunya karena dapat mengurangi pelaku korup di dalam birokrasi pemerintahan. Namun prinsip good governance yang diperkenalkan oleh World Bank mendapat sejumlah kritikan. Salah satu kritik yang diberikan adalah kurangnya kontrol yang dilakukan dalam penerapan good governance di dalam pemerintahan. Tidak hanya itu penerapan good governance di dalam suatu negara seringkali dipaksakan walaupun prinsip tersebut tidak cocok dengan sistem pemerintahan, negara, budaya masyarakat yang ada.

Prinsip Good Governance yang diciptakan World Bank justru dianggap tidak dapat menyelesaikan masalah kemiskinan terutama di negara-negara berkembang (Scholte, 2012). Apalagi ketika prinsip neoliberalisme yang diperkenalkan pada tahun 1946 oleh sekelompok jaringan masyarakat yang suskes menerapkan suatu hegemoni kebijakan dibeberapa negara di dunia. Neoliberalisme kemudian masuk dan diterapkan dalam setiap kebijakan ekonomi di negara maju. Neo Liberalisme merupakan suatu paham yang menganut prinsip-prinsip seperti mengutamakan investasi asing yang masuk ke suatu negara, menciptakan kondisi yang seimbang antara investasi internal dan eksternal, melegalkan ijin-ijin usaha dan menasionalisasikan investasi asing. Hal ini menbuat ekonomi di suatu negara akan semakin maju, namun menciptakan krisis di negara belahan dunia lainnya. Sehingga tujuan good governance yang digagas oleh World Bank untuk memberantas kemiskinan di negara berkembang, justru gagal diimplementasikan. Selain itu, praktek good governance yang digagas oleh UNDP pun menuai kritik. UNDP mengusung good governance dalam frame democratic governance. Konsep untuk good governance tidak bisa serta merta di implementasikan di suatu negara, perlu adanya penyesuaian terhadap kharakteristik kondisi dan karakteristik dari masing-masing negara. Alhasil, good governance ketika dipaksakan di suatu negara bisa menjadi cacat. Artinya konsep good governance ini mencoba untuk menerjang tatanan yang ada di negara tersebut dengan memasukkan prinsip-prinsip yang diusung oleh UNDP. Hal ini bisa menghilangkan prinsip-prinsip lokalitas yang murni berasal dari negara yang bersangkutan. Lebih lanjut, negara-negara donor juga mempunyaii keberagaman politiik dan kapitalisme yang dapat mempengaruhi negara-negara yang menerima donor tersebut.

Good Governance mulai muncul di Indonesia setelah era reformasi. Hal ini dilatar belakangi oleh berbagai macam permasalahan yang muncul Tuntutan pemerintah orde baru yaitu presiden sebagai pusat kekuasaan. sebagai akibat dari konstitusi maupun akibat dari lembaga tinggi negara lainnya yang tidak berjalan dengan baik, dan juga tersumbatnya control social yang berasal dari partisipasi masyarakat. Namun pada kenyataannya, hingga saat ini pun masih belum menemukan pemaham yang baik mengenai apa itu good governance sehingga dalam implementasinya, konsep ini belum dapat berjalan dengan baik. Pemerintahpun mulai mempunyai komiten untuk menjadikan good governance sebagai landasan atau pondasi nilai pemerintahan. 
Pada masa reformasi, badan eksekutif dan legislatif telah berhasil menciptakan 3 perundang-undangan yang kemudian mengubah sistem dalam pemerintahan di Indonesia, yaitu:

1. Undang-Undang Nomor 32 tahun 2004 yang membahas mengenai pemberian kewenangan yang lebih besar untuk daerah (Kabupaten dan Kota) untuk dapat mengatur dan mengelola bidang pemerintahan dan juga bidang pembangunan. Undang undang ini berimplikasi terhadap kebijakan dan perencanaan sebagai dampak dari bergesernya kewenangan pada hal tersebut dengan adanya kebijakan yang terdesentralisasi, maka daerahpun mempunyai kewenangan. Dengan adanya sistem yang terdesentralisasi ini, daerah mempunyai kewenangan untuk dapat menetapkan kebijaksanaan dalam hal perencanaan dan pembangunan daerah.

2. Undang-undang Nomor 28 Tahun 2004 yang membahas mengenai pemberian wewenang yang lebih besar dalam pengelolaan dan pengalokasian dana kepada pemerintah daerah (Kabupaten atau kota). Lebih umumnya undang-undang ini mengatur tata pelaksanaan ini mengatur pelaksanaan perimbangan dalam bidang keuangan antara pusat dan daerah.

3. Undang-Undang Nomor 28 tahun 1999 mengenai pelaksanaan pada bidang pembangunan dan pelaksanaan pemerintahan ditingkat pusat dan daerah sebagai bentuk pengimplementasian pemerintahan yang baik. Undang-undang tersebut merupakan landasan utama diterapkannya konsep Good Governance sebagai landasan penyelenggaraan pemerintahan yang memiliki orientasi membangun citra pemerintahan sebagai pemberi layanan yang adil kepada masyarakat.

Ketiga undang-undang tersebut merupakan pondasi utama diterapkannya konsep Good Governance dalam menyelenggarakan pemerintahan yang berorientasi kepada pembangunan citra pemerintahan sebagai pemberi layanan yang adil.

\section{Metode Penelitian}

Paradigma pada penulisan ini adalah kualitatif, dengan tipe penelitian yang deskriptif. Proses analisis data yang dilakukan secara menyeluruh dengan teknik pengambilan data dalam penulisan ini yaitu melalui studi literature/tinjauan pustaka. Tinjauan pustaka yang dilakukan dalam penelitian ini adalah dengan pencarian berbagai referensi atau sumber yang relevan terkait dengan penulisan ini berupa buku, jurnal, hasil penelitian, dan lain-lain.

\section{Hasil Dan Pembahasan}

Good Governance ialah tata kelola pemerintahan yang baik. Dalam mewujudkan konsep good governance maka diperlukan sinergi anatar tiga aktor utama, yakni pemerintah, privat sector, dan civil society. Ketiga aktor ini mempunyai peran dalam mengelola sumber daya, lingkungan social, ekonomi, dan budaya. Pengertian good governance dalam versi World Bank diartikan sebagai penyelenggaraan pengelolaan atau manajemen dalam pemerintah secara solid dan akuntabel aerta berdasarkan prinsip pasar yang efisien dan juga pencegahan korupsi baik secara administratif maupun politis. Hal ini bagi sektor pemerintah atau sektor privat sekalipun merupakan suatu inovasi atau terobosan yang mutakhir dalam upaya menciptakan kredibilitas publik manajerial yang handal. Good Governance ini hadir sebagai salah satu bentuk solusi dalam mengatasi permasalahan yang terjadi dalam suatu negara. Good Governance membantu mengintegrasikan anatar peran pemerintah, privat 
sector, dan masyarakat untuk mencapai konsesus bersama, dimana dalam pelaksanaannya dapat di pertanggungjawabkan dan bersifat efektif dan efesien. Dengan memperhatikan nilainilai dan cara kerja good governance, maka hal ini bisa memperkecil terjadinya penyimpangan dalam pelaksanaan kebijakan karena program-program yang yang ditetapkan adalah berdasarkan keputusan bersama.

Negara yang berperan dalam pemberi layanan kepada masyarakat demi tercapainya kesejahteraan secara adil dapat berjalan dengan baik apabila sistem pemerintahnya memegang teguh pada 3 dasar pembangunan berkelanjutan, yaitu bidang lingkungan, ekonomi dan sumber daya manusia. Konsep good governance ini memiliki keterkaitan dengan 3 aktor utama, yaitu: Pemerintah sebagai penyelenggara negara, korporat sebagai penggerak bidang perekonomian, serta masyarakat sipil sebagai pihak penyesuai. Pihak pihak tersebut saling mempengaruhi dan masing masingnya memiliki peran dalam penyelenggaraan negara yang baik. Sinkronisasi dan harmonisasi antar pihak-pihak tersebut menjadi jawaban besar. Namun dengan keadaan Indonesia saat ini masih sulit untuk dapat terjadi (Efendi, 2005). Konsep good governance ini dapat diwujudkan melalui upaya adanya kesinergian antara masyarakat sipil, sektor publik, dan sektor privat dalam mengelola sumber daya alam, ekonomi, lingkungan dan sosial. Good governance sekurang-kurangnya harus dapat mencapai prasyarat adanya partisipasi, efesiensi dan efektivitas, transparansi, dan keadilan.

Konsep Good governance yang diusung oleh World Bank dan UNDP masih belum memiliki kesepakatan yang pasti. Konsep ini lebih dimaknai sebagai solusi untuk perwujudan kinerja pemerintah yang efektif dan efesien. Lebih lanjut, World Bank sebagai lembaga donor memberikan bantuan kepada negara-negara untuk membangun kapasitas institusi dan pelatihan bagi pejabat public guna meningkatkan kompetensinya. Keberhasilan dari konsep good governance bisa dipahami melalui prinsip-prinsip yang ada didalamnya. Prinsi-prinsip ini digunakan sebgai tolok ukur kinerja pemerintah dalam mengelolah pemerintahan. Prinsipprinsip yang ada pada good governance antara lain sebagai berikut:

1. Partisipasi Masyarakat

Partisipasi masyarakat ialah keikutsertaan masyarakat dalam pengambilan keputusan, baik secara langsung maupun melalui perwakilan lembaga-lembaga yang sah untuk mengakomodir kepentingan warga masyarakat. Partisipasi masyarakat dibangun berdasarkan prinsip kebebasan yang adil dan santun. Dengan adanya partisipasi dari masyarakat akan membuat suatu kebijakan menjadi lebih hidup, karena memiliki ruk yang berasal dari lokalitas warga yang bersangkutan.

2. Supremasi Hukum

Hukum memiliki peranan penting dalam menegakkan keadilan dan kebenaran. Hukum yang dibuat haruslah bersifat tidak memihak, adil, dan konsisten. Hukum harus diberlakukan tanpa pandang bulu, tidak melihat pada jabatan, materi, dan kekerabatan.

3. Transparansi

Transapari atau bias diartikan dengan keterbukaan adalah pemerintahan memberikan kemudahan akses informasi kepada masyarakat terkait dengan kegiatan penyelenggaraan pemerintahan. Informasi bisa diakses oleh semua warga masyarakat dengan memperhatinkan pada ketentuan-ketentuan yang telah dibuat. Informasi haruslah bersifat update dan dapat dipertanggungjawabkan kebenarannya. 


\section{Stakeholder}

Stakeholder mempunyai peranan penting dalam membangun kemitraan dengan pemerintaan. Stakeholder disini bisa berkedudukan sebagai pengambil keputusan atau pelaksana program.

Stakeholder mempunyai kepentingan tersendiri yang mana seharusnya berjalan selaras dengan kepentingan yang dibangun oleh pemerintah dan masyarakat.

5. Berorientasi pada Konsensus

Pemerintah memiliki peran sebagai katalisator yakni menjembatani berbagai aspirasi dan kepentingan-kepentingan sehingga nanti bisa didapat sebuah konsesus yang berdasar pada kesepakatan bersama.

6. Kesetaraan

Seluruh warga masyarakat memiliki kesempatan yang sama dimata hukum dan untuk mencapai kesejahteraannya. Prinsip kesetaraan akan memacu dampat keadilan dan pembangunan ekonomi yang stabil, karena semua rakyat memiliki hak dan kesempatan yang sama untuk melakukan pengembangan diri tanpa adanya intervensi dari pihak manapun.

7. Efektifitas dan Efisiensi

Dalam menjalan program-program dan kebijakan, pemerintah berpegang pada prinsip efektif dan efesien. Dimana program dikatakan efektif, jika program yang dijalankan dapat berjalan sesuai dengan yang telah ditetapkan sebelumnya. Pun dengan efesien, artinya pemerintah harus menggunakan anggaran dengan sebaik-baiknya sesuai dengan kebutuhan yang akan dilakukan.

8. Akuntabilitas

Akuntabilitas adalah segala bentuk kegiatan/program yang telah dilaksanakan dapat dipertanggungjawabkan kepada masyarakat. Bentuk pertanggungjawaban dapat berbedabeda tergantung dari pihak yang terkait. Akuntabilitas yang dilakukan oleh pemerintah dapat meningkatkan kepercayaan masyarakat.

9. Visi Strategis

Visi strategis merupakan cara pandang yang digagas oleh pemerintah dan masyarakat dalam membangun ekonomi manusia untuk mewujudkan kesejahteraan masyarakatnya. Visi strategis adalah rancangan kegiatan/program apa yang ingin dicapai untuk mewujudkan tujuan negara. Cara pandang yang strategis akan membuat suatu negara untuk mempertahankan eksistensinnya.

Sedangkan menurut United National Development Program (UNDP) prinsip good governance, terbagi menjadi 14, yaitu:

1. Partisipasi Masyarakat

2. Wawasan ke Depan

3. Keterbukaan dan Transparansi

4. Demokrasi

5. Profesionalisme dan Kompetensi

6. Kemitraan dengan Dunia Usaha Swasta dan Masyarakat 
7. Desentralisasi

8. Komitmen pada Lingkungan Hidup

9. Komitmen pada Pengurangan Kesenjanga

10. Profesionalisme dan Kompetensi

11. Keefisienan dan Keefektifan

12. Daya Tanggap

Good Governance di Indonesia dikenal sejak era reformasi. Perkembangan good governance di Indonesia pun juga dipengaruhi oleh krisis monetar dan kondisi sejarah negara lainnya. Krisis ekonomi yang melanda Indonesia disebabkan oleh banyak hal, diantaranya tata kelola pemerintahan yang buruk, maraknya KKN (Korupsi, Kolusi, dan Nepotisme). Praktik KKN menjadi perhatian serius dan menjangkiti hampir semua elemen pemerintahan. Dampak dari permasalahan ini adalah kualitas pelayanan masyarakat yang buruk. Masyarakat seperti dipandang sebelah mata. Para penyelenggara pemerintahan hanya sibuk untuk mengisi perut dan memenuhi kepentingannya. Hal ini tentunya menghabat proses pembangunan, merabaknya kriminalitas, meningkatnya jumlah pengangguran, bertambah jumlah penduduk miskin, tingkat kesehatan menurun, kualitas pendidikan yang buruk, dan munculnya konflik didaerah yang mengancam persatuan dan kesatuan NKRI. Penerapan good governance di Indonesia pada waktu itu bisa dikatakan sebagai angin segar yang dapat memperbaiki sistem yang korup dan kualitas pelayanan masayarakat yang buruk. Berikut beberapa permasalahan good governance di Indonesia:

1. Belum adanya kesesuaian antara tuntutan kebutuhan masyarakat dengan reformasi birokrasi yang berjalan.

2. Tingginya tingkat keberagaman masalah dalam mencari keputusan akhir atau pernyelesaianya.

3. Tren penyalahgunaan dan pelanggaran wewenang dan perilaku dan tindakan Korupsi Kolusi dan Nepotisme yang masih tinggi, serta pengadaan kontrol dan pengendalian kinerja aparatur pemerintah yang masih lemah.

4. Partisipasi masyarakat yang semakin tinggi tuntutannya dalam pembuatan dan pengimplementasian kebijakan publik.

5. Tuntutan publik terhadap pelaksanaan prinsip prinsip Good Governance yang semakin meningkat, dalam rangka untuk memperbaiki dan meningkatkan tata kelola kepemerintahan.

6. Era desentralisasi, yang berakibat pada meningkatnya tuntutan dalam pelimpahan kewenangan, tanggung jawab dan pengambilan keputusan.

7. Belum memadainya sistem kelembagaan dan tata kelola pemerintahan di daerah sehingga menyababkan rendahnya kinerja sumber daya aparatur pemerintahan terkait.

Berbagai upaya dalam mewujudkan tata kelola pemerintahan yang baik telah dilakukan, namun apabila dilihat dalam perkembangan Good Governance di Indonesia, pada pengimplementasiannya masih terdapat kebocoran akibat kurangnya transparansi sebagai salah satu syarat pokok dari Good Governance, sehingga pengimplementasiannya ini belum dapat dikatakan baik dan berhasil sepenuhnya. Hal tersebut dapat dilihat dalam data-data sebagai berikut: 


\section{Indeks Persepsi Korupsi}

Pemerintahan yang bersih merupakan syarat dalam tata kelola pemerintahan yang baik, salah satu indikatornya adalah angka korupsi, jika dilihat angka Indeks Persepsi Korupsi dari tahun ke tahun Indonesia memang mengalami perbaikan, namun tingkat korupsi di Indonesia masih relatif tinggi apabila dibandingkan dengan Negara Negara Asia Tenggara lainnya. Data dari Transparansi Internasional Indonesia menyebutkan bahwa pada tahun 2014 Indeks Persepsi Korupsi Indonesia masih tinggi (peringkat 107) tertinggal dari Thailand dan malaysia, dan jauh tertinggal dari Singapura yang menempati peringkat 7.

TABEL INDEKS PERSEPSI KORUPSI

\begin{tabular}{|c|c|c|c|c|}
\hline Negara & $\begin{array}{c}\text { Ranking } \\
\text { (tahun 2014) }\end{array}$ & $\begin{array}{c}\text { Nilai 2012 } \\
\text { (skala 0-100) }\end{array}$ & $\begin{array}{c}\text { Nilai 2013 } \\
\text { (skala 0-100) }\end{array}$ & $\begin{array}{c}\text { Nilai 2014 } \\
\text { (skala 0-100) }\end{array}$ \\
\hline Singapura & 7 & 87 & 86 & 84 \\
\hline Brunei & - & 55 & 60 & 50 \\
\hline Malaysia & 52 & 49 & 50 & 38 \\
\hline Filipina & 85 & 34 & 36 & 38 \\
\hline Thailand & 85 & 37 & 35 & 34 \\
\hline Indonesia & 107 & 32 & 32 & 25 \\
\hline Vietnam & 119 & 31 & 31 & 21 \\
\hline Laos & 145 & 21 & 26 & 21 \\
\hline Myanmar & 156 & 15 & 21 & 20 \\
\hline Kamboja & 156 & 22 & & 21 \\
\hline
\end{tabular}

Sumber: Transparansi Internasional Indonesia, 2014

Gambar 3.1

Data Penyelewengan Kekuasaan Berdasarkan Profesi/Jabatan

\begin{tabular}{|c|c|c|c|c|c|c|c|c|c|c|c|c|c|c|}
\hline JABATAN & 2004 & 2005 & 2006 & 2007 & 2008 & 2009 & 2010 & 2011 & 2012 & 2013 & 2014 & 2015 & 2016 & JUMLAH \\
\hline Anggota DPR dan DPRD & o & o & o & 2 & 7 & $\mathbf{8}$ & 27 & 5 & 10 & 8 & 9 & 19 & 23 & 124 \\
\hline $\begin{array}{l}\text { Kepala } \\
\text { Lembaga/Kernenterian }\end{array}$ & $\circ$ & 1 & 1 & $\circ$ & 1 & 1 & 2 & o & 1 & 4 & 9 & 3 & 2 & 25 \\
\hline Duta Besar & 0 & o & o & 2 & 1 & o & 1 & o & o & o & o & o & o & 4 \\
\hline Komisioner & - & $\mathbf{3}$ & 2 & 1 & 1 & $\circ$ & o & $\circ$ & o & - & 0 & o & o & 7 \\
\hline Gubernur & 1 & $\circ$ & 2 & 1 & 1 & 2 & 1 & o & o & 2 & 3 & 3 & 1 & 17 \\
\hline $\begin{array}{l}\text { Walikota/Bupati dan } \\
\text { Wakill }\end{array}$ & $\circ$ & o & 3 & 6 & 6 & 5 & 4 & 3 & $\mathbf{3}$ & $\mathbf{3}$ & 12 & 4 & 7 & 56 \\
\hline Eselon 1/11/ / & 2 & 9 & 15 & 10 & 22 & 14 & 12 & 15 & $\mathbf{8}$ & 7 & 2 & 7 & 8 & 131 \\
\hline Hakim & $\circ$ & - & $\circ$ & o & o & o & 1 & 2 & 2 & $\mathbf{3}$ & 2 & $\mathbf{3}$ & 1 & 14 \\
\hline Swasta & 1 & 4 & 5 & 3 & 12 & 11 & 8 & 10 & 16 & 24 & 16 & 18 & 26 & 154 \\
\hline Lainnya & $\circ$ & 6 & 1 & 2 & 4 & 4 & 9 & 3 & 3 & $\mathbf{8}$ & 8 & 5 & 23 & 76 \\
\hline Jumlah Keseluruthan & 4 & 23 & 29 & 27 & s5 & 45 & 65 & $\mathbf{3 8}$ & 49 & 50 & 61 & 62 & 91 & 608 \\
\hline
\end{tabular}

Sumber: Komisi Pemberantasan Korupsi. 2016

Dari gambar diatas dapat dilihat bahwa tindak pidana korupsi profesi hakim sampai tahun 2016 totalnya 14 kasus. Tentunya hal ini memprihatinkan karena tonggak keadilan di pengadilan ditentukan oleh hakim. Saat hakim bertindak tidak professional atau berpihak pada golongan tertentu, hal ini akan berdampak merugikan pada pihak yang lainnya. 


\section{Kemudahan Dalam Berbisnis (Ease of doing business)}

Pada tahun 2015, World Bank mengeluarkan sebuah data tahunan terkait dengan kemudahan dalam melakukan bisnis di seluruh dunia. Laporan data tersebut memperlihatkan bahwa Indonesia hanya menempati rangking 114 di tingkat dunia dalam kemudahan berbisnis, tertinggal jauh dari negara-negara di sekitarnya. Singapura berada di peringkat 1 , Malaysia 18, Thailand 26, Vietnam 78, Filipina 95 dan Brunei 101.

\section{Indeks Daya Saing Global (Global competitiveness index)}

Indeks daya saing global merupakan ukuran daya saing setiap negara dilihat dari beberapa aspek, yaitu pendidikan dasar dan kesehatan, pendidikan tinggi dan pelatihan, kelembagaan, infrastruktur, lingkungan makro ekonomi, pengembangan pasar keuangan, ukuran pasar, efisiensi pasar tenaga kerja, efisiensi pasar barang, kecanggihan bisnis, kesiapan teknologi, dan inovasi. World Economic Forum, sebagai lembaga internasional yang berwenang untuk membidangi ini, pada tahun 2015 mengeluarkan sebuah data yang memperlihatkan Indonesia berada di posisi ke 4 diantara negara ASEAN dan urutan ke 34 di dunia. Sedangkan Singapura berada jauh di depan, bahkan menjadi peringkat 2 di dunia. Malaysia berada diurutan berikutnya dengan rangking ke 20 sedangkan Thailand berada di urutan ke 31. Sebagaimana gambar berikut ini:

Gambar 3.2

Peringkat Global Competitiveness Index

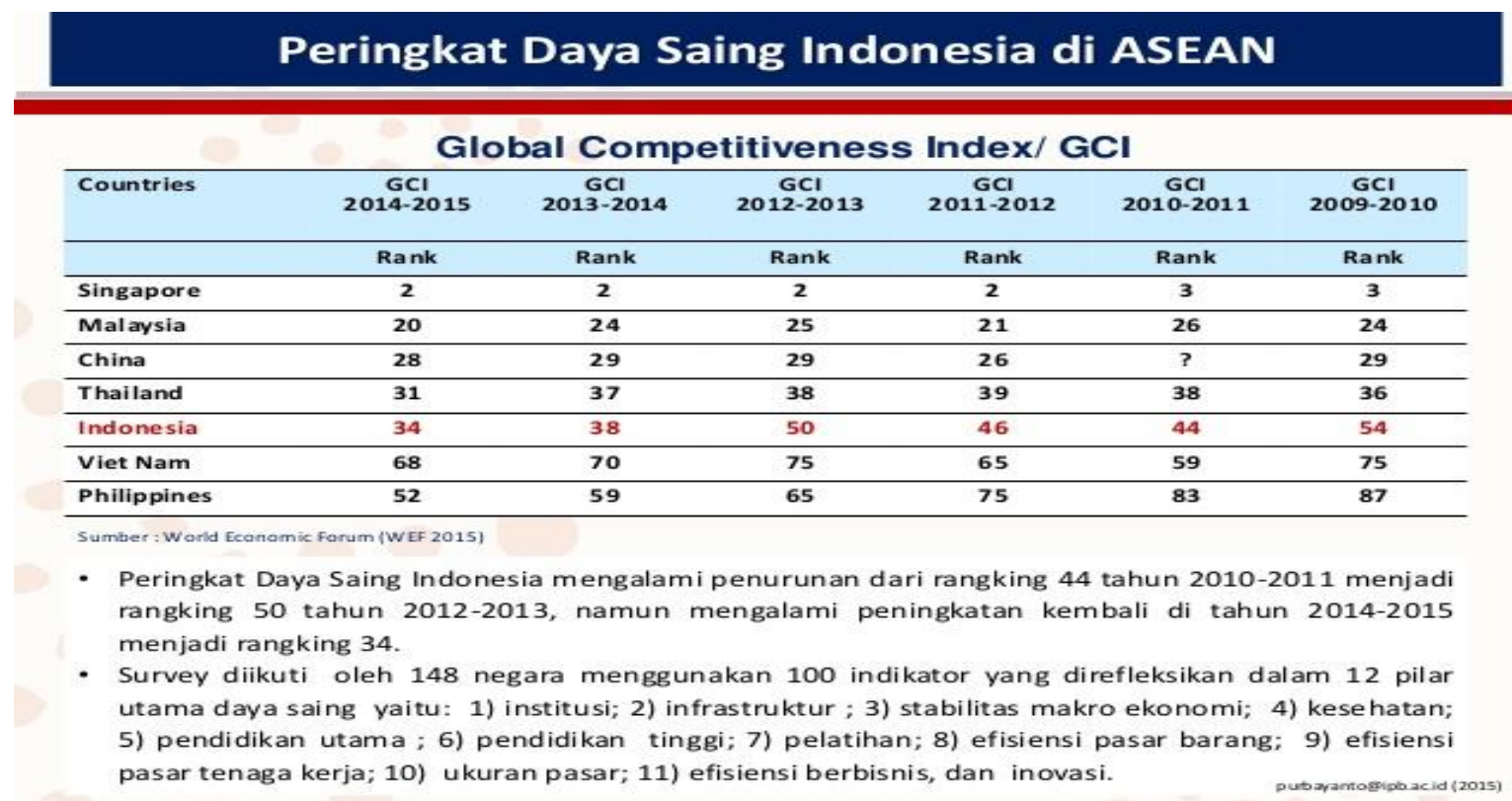

4. Indeks Pembangungan Manusia (IPM)

Indeks Pembangunan Manusia (IPM) merupakan sebuah indikator kinerja pembangunan yang mengukur tiga dimensi pokok pembangunan manusia. Tiga dimensi pokok tersebut diantaranya adalah angka usia harapan hidup, capaian tingkat pendidikan (Angka Rata-Rata Lama Sekolah dan Angka Harapan Lama Sekolah), dan pengeluaran per kapita. Tahun 2015, dibandingkan negara-negara di ASEAN, IPM Indonesia menempati posisi 5 masih tertinggal dari Singapura, Brunei, Malaysia dan Thailand. 


\section{Indeks Efektifitas Pemerintahan}

Menurut The Global Economy, indeks efektivitas Pemerintahan Indonesia tahun 2013 adalah -0,24 dengan menempati urutan ke-103 dari 192 negara. Posisi Indonesia masih tertinggal dibandingkan dengan negara ASEAN lain, seperti Malaysia (indeks 1,10 di urutan ke-35), Thailand (indeks 0,21 di urutan ke-72), dan Filipina (indeks 0,06 di urutan ke-79). Sebagaimana gambar berikut ini:

\section{Government effectiveness}

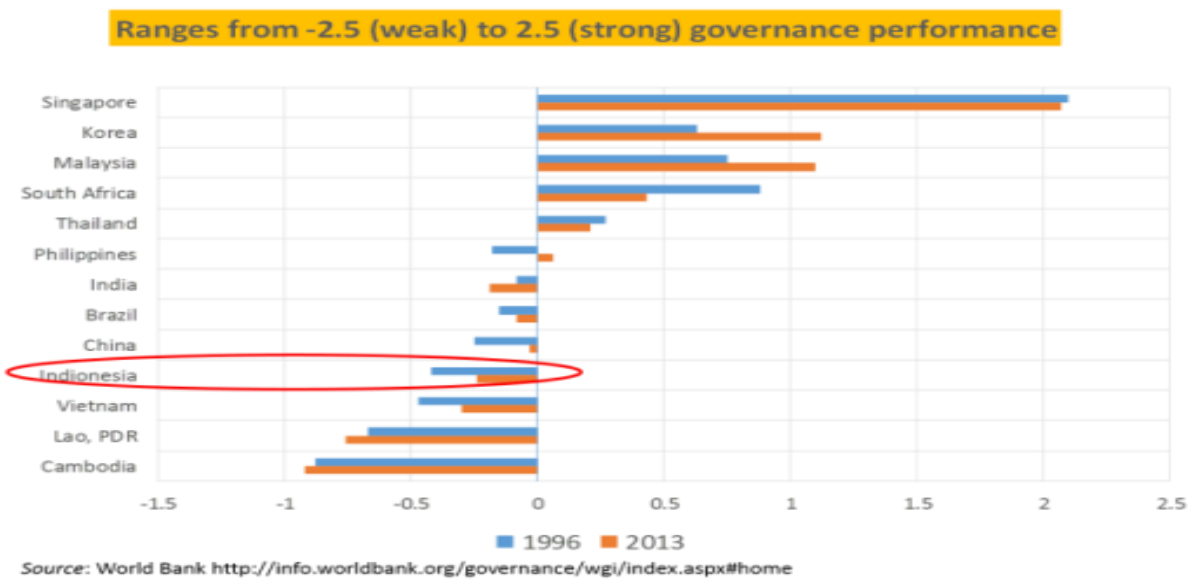

Bank Dunia memperkenalkan konsep good governance di Indonesia dengan tiga pintu yaitu Consultative Group on Indonesia, Partnership for Governance Reform, dan Justice for the Poor. Setiap kali menyelenggarakan forum tahunan CGI, Bank Dunia selalu terdepan dalam memimpin pengarahan kebijakan ekonomi melalui pembuatan peraturan perundangundangan. Hal ini dapat terjadi mengingat bahwa pemerintahan Indonesia masih menerima pemberian hutang sehingga mengaharuskan adanya kompensasi yang juga perlu dipenuhi. Selain itu, Bank Dunia juga bekerja sama dengan UNDP dan ADB yang mana merupakan sponsor dana terbesar bagi Partnership for Governance Reform. Dengan kata lain, sebenanrnya Bank Dunia telah secara proaktif menguasai Indonesia dalam hal pembuatan kerangka hukum untuk sebuah pembangunan bangsa. Sedangkan Justice for the Poor mengandung makna bahwa Bank Dunia telah membuat institusi yang baru-baru dalam mendukung pengentasan kemiskinan di Indonesia. Dalam urusan pembaruan ketata laksanaan pemerintahan, Bank Dunia cenderung melayani pembaruan sosial dan ekonomi, khususnya dengan mengaplikasikan pemberdayaan teknokratik dan bahasa liberal partisipasi. Di titik ini, diskursus dan arah kecenderungan hak-hak asasi manusia lebih menyesuaikan dengan liberalisasi pasar. Inilah yang disebut "market friendly human rights paradigm" atau cara pikir dan cara kerja pemerintah untuk membuat nyaman dan mendukung hak-hak pasar.

Projek good governance yang diinisiasi oleh World Bank tersebut kemudian menuai beberapa tanggapan yang menglobal baik itu berupa kritik serius atau bahkan pujian. Sebagai sampel, yaitu Julius K. Nyerere, eks Presiden Tanzania, yang mengkritik prinsip "good governance" sebagai sebuah konsep yang imperialistik dan koloni pada saat berpidato di UN Conference on Governance di Afrika tahun 1998 silam. Sang Presiden memandang bahwa projek tersebut sebagai sebuah projek kekuasaan Barat yang mengkapitalisasi industri dan korporasi global transnasional, yang dipaksakan untuk negara negara berkembang seperti Afrika dan Asia. Secara jelas, projek ini menganggap bahwa governansi di negara-negara berkembang tersebut tengah berada pada situasi yang mengkhawatirkan sehingga perlu ada 
upaya perubahan dan perbaikan dengan cara mengurangi peran negara dan masyarakat. Namun, negara perlu memberikan ruang yang luas dan nyaman bagi sektor bisnis melalui konsep privatisasi, serta membuat arah yang baik bagi setiap korporasi kapitalis global untuk mencari profit tinggi dan menghasilkan perpaduan ke dalam sistem pasar global (UNDESA, 1998).

Farazmand (2004) juga mengkritik prinsip good governance bahwa tiga interaksi kekuatan yang dianggap melibatkan good governance adalah interaksi antar negara, masyarakat sipil, dan sektor privat. Namun interaksi mengabaikan kekuatan paling penting yang mempengaruhi governance di negara berkembang dan kurang maju yakni struktur kekuatan internasional, kekuasaan negara global, dan elit korporat trans-dunia. Menurut Farazmand, hubungan interaksi antar ketiga aktor ini harus dilengkapi dengan struktur kekuatan internasional/global, yang mana dari permasalahan inilah kemudian muncul konsep sound governance.

\section{Referensi}

Agus, D. (2005). Mewujudkan Good Governance Melalui Pelayanan Publik. Yogyakarta: Pustaka Pelajar.

Creswell, J.W. (2013). Research Design. Pustaka Pelajar. Yogyakarta

Domai, T.(2011). Sound Governance. UB Press. Malang.

Effendi, S. (2005). Membangun Good Governance Tugas Kita Bersama. Yokyakarta

Farazmand, A. (2004). Sound Governance Policy and Administrative Innovation. Preage, Westport, Connection. London.

Farhan, A. (2015). Perbandingan Daya Saing Indonesia dengan Negara-Negara ASEAN. National University of Malaysia.

Heriyani, Y. (2007). Pengaruh Pelaksanaan Prinsip-prinsip Good Governance Terhadap Pelayanan. Universitas Sumatera Utara. Medan

Sumarto, H.S.J. (2003). Inovasi Partisipasi dan Good Governance. Jakarta: Yayasan Obor Indonesia

Jamil, I, dkk. (2013). In Search of Better Governance in South Asia and Beyond. Bussiness Media. New York.

Narang, A.T. (2007). Good Governance dan Clean Government dalam Implementasinya di Propinsi Kalimantan Tengah; Seminar Nasional Pergeseran Paradigma Kepemerintahan Dari Government ke Governance: Teori dan Praktek. Komap Fisipol UGM

Pratikno. (2005). Dari Good Governance menuju Just \& Democratic Governance. dipresentasikan dalam Pelatihan Pengawasan Pemerintahan. Sleman. USC Satunama.

Prianto, A. L. (2011). Good Governance dan Formasi Kebijakan Publik Neo-Liberal. Otoritas: Jurnal Ilmu Pemerintahan, 1(1).

Sedarmayanti. (2012). Good Governance "Kepemerintahan yang Baik. Bagian Kedua Edisi Revisi. Bandung: CV Mandar Maju. 
Siamat, D. (2004). Manajemen Lembaga Keuangan. Edisi Keempat, Lembaga Penerbit Fakultas Ekonomi Universitas Indonesia.

Sulistiyani, T.A. (2011). Memahami Good Governance Dalam Perspektif Sumber Daya Manusia. Yogyakarta: Gava Media.

Tangkillisan, H.N. S. (2005). Manajemen Publik. Jakarta: Gramedia WidiaSarana Indonesia. 